\title{
Improving Geometry Volume Calculation Ability through Jigsaw Model
}

\author{
Nuning Rahmawati \\ Postgraduate of Elementary Education \\ Universitas Negeri Surabaya \\ Surabaya, Indonesia
}

\begin{abstract}
Based on the reality, common mistake in the beginning of learning is when students do not have learning goal. Researchers wanted to change the mindset of students so they are more motivated to be actively involved in learning. The JIGSAW Learning Model was considered to be the most appropriate method because the students felt that their active role was very influence to the assessment of the group. The JIGSAW learning model gave them equal responsibility in a solid group.
\end{abstract}

Keywords-The same roles and responsibilities in the group.

\section{INTRODUCTION}

Mathematics learning no longer focuses on absorption through the achievement of information, but rather prioritizes the development of information capability and processing. For that the activities of learners need to be improved through exercises or math tasks by working in small groups and explaining ideas to others [1].

Mathematics lesson in the $6^{\text {th }}$ grade, the material is about geometrical. This material is not a new lesson for $6^{\text {th }}$ grade students because the material has been delivered in the $5^{\text {th }}$ grade. However, the material in the $6^{\text {th }}$ grade is more difficult than the previous one.

Although this lesson is repeated, but they tended to be lazy, less concerned, and crowded. They were also lazy to work on a difficult problem. This conclusion was drawn from the analysis of two daily tests with Standart Competences of calculating the area of many simple facets, the area of the circle and the volume of simple prism and Basic Competence of calculating the volume of other space geometry. In the first daily test the average student test result was below 50 , which was 47 . The most common mistake done by the students was when calculating the volume of tubes and cones and finding the length of one side of the wake whose volume had been known. In the second daily test, the average test result was not much different, the mistakes were also the same.

Temporary suspicion, students' difficulties in finding the geometry volume were derived from improper learning models. During this time the teacher only used lecturing method, so that students just listened to the teacher. This made the students were quiet, less active and not creative.

So, in this study the researchers applied cooperative learning model of JIGSAW type to overcome the problems of mathematics learning which appeared in the class of VI-A SDN Sambungrejo, Sukodono, Sidoarjo

From the above background, the researcher proposed a research entitled "Improving Geometry Volume Calculation Ability through Jigsaw Model".

\section{LITERATURE REVIEW}

\section{A. Cooperative Learning Model}

Cooperative learning involves understanding learning material through uses small groups in which students work together to learn, discuss, share knowledge, communicate with one another, and help them understand the subject matter. Cooperative learning has a broader understanding than just group work. In cooperative learning each group member is responsible for the success of his group members in achieving the learning objectives [2]. Cooperative learning is developed for at least three important learning objectives, namely academic learning outcomes, acceptance of diversity, and social skills development [3].

Slavin [4] defines cooperative learning as a learning technique in which students work in a heterogeneous group of 4 to 6 . The heterogeneity of group members can be observed from gender, ethnicity, academic achievement and social status.

a) Based on some notions of cooperative learning mentioned above, there is a shift in the role of central teachers to the role of teachers who manage student learning activities through teamwork in the classroom. For that Ibrahim, et al [3] suggests the characteristics of cooperative learning methods, among others.

b) Students cooperate in groups cooperatively to complete their learning materials.

c) Groups formed from students with high, medium and low ability.

d) Where possible group members come from different races, tribal cultures and genders.

e) The award is more group-oriented than the individual.

These characteristics put this cooperative learning method unique, because in addition to helping students understand the subject matter also train students' skills in group cooperation. 
This cooperative learning method has many methods or techniques. According to Robinson [5], there are several models in cooperative learning are: TGT (Teams-GamesTournament), TAI (Teams Assisted Individualization), LT (Learning Together), Gl (Group Investigation), Jigsaw, STAD (Student-Teams -Achievement-Division).

\section{B. JIGSAW Type Co-operative Learning}

The Jigsaw method is a cooperative learning technique in which students, not teachers, have a greater responsibility in implementing learning. The purpose of the jigsaw is to develop teamwork, cooperative learning skills, and master deep knowledge that is not possible if they try to learn all the material alone.

Every student in the "early group" specializes in one part of a learning unit. The students then meet with other group members assigned to work on the other part, and after mastering these other lessons they will go back to their original group and inform the material to the other members [6].

After mastering this new lesson, all the students return to the "early group" and each member shares their newly learned knowledge in the "jigsaw" group. As in the "jigsaw puzzle", each piece of the image - the analogy of each the knowledge part - is essential to the complete completion and understanding of the end result

Jigsaw is an active learning technique commonly used because it maintains a high level of personal responsibility. According to Garfield [7], the facilitator can set the jigsaw strategy in two ways:

\section{1) Homogeneous grouping}

Instructions: Group the participants who have the same number card. For example, participants will be organized into discussion groups based on what they read. Therefore, all participants who read Chapter 1, Chapter 2, etc., will be placed in the same group. Prepare four folding papers, fold each into two into a nameplate, number 1 to 4 and place it on the table.

Advantages: This grouping allows participants to share different perspectives of the same reading, potentially caused by a deeper understanding of one of the chapters. Greater potential for generating the analytical process than simply a simple narrative.

Weaknesses: the focus is narrow (one chapter) and possibly overkill.

\section{2) Heterogenous grouping}

Instructions: Place the participants who have different numbers to sit together. For example, each discussion group is likely to consist of 4 individuals: one who has read Chapter 1, one who has read Chapter 2, etc. Prepare four folding papers, fold each into two into a nameplate, number 1 to 4 and place it on each table. Let the participants find their own place according to the chapters they have read based on "who they can get quickly".
Advantages: Allows "peer instruction" and knowledge gathering, providing participants with information from chapters they do not read.

Weaknesses: If one participant does not read the assignment, the information can not be shared / discussed.

\section{Understanding Achievement}

Achievement is the result someone has achieved in doing the activity. Gagne and Merrill [8] state that learning achievement is divided into five aspects, namely: intellectual ability, cognitive strategy, verbal information, attitudes and skills. According to Bloom et al [9], learning outcomes can be divided into three aspects, namely cognitive, affective and psychomotor.

The cause of the low mathematics learning outcomes in particular calculate the volume of waking space in grade 6 students SDN Sambungrejo Sukodono Sidoarjo, among others: 1) The pattern of teaching so far is still with the stages of providing information about the materials of a lecture. 2) There is no interactive relationship between student and teacher in learning and 3) There is no direct involvement of students so that students are only passive. To overcome the problem of low learning outcomes of students in learning mathematics is the need for a fun learning. For elementary students the learning needs are usually based on a strong will to satisfy their curiosity, because the important thing for children is to learn while playing.

By using appropriate methods and strategies the teacher will more easily instill the concept to be taught. Thus, to improve learning outcomes of mathematics students of class VI SDN Sambungrejo Sukodono Sidoarjo especially in calculating the volume of wake space can be done using JIGSAW cooperative learning model type.

\section{RESEARCH METHODS}

\section{A. Subject, Place and Time of Research}

This research was conducted in class VI-A SDN Sambungrejo Sukodono Sidoarjo on October 9, 2017 until October 24, 2017 in Mathematics subject.

Design Procedures for Improvement of Learning activity planning is the most decisive part in the implementation of PFM. The improvement plan is intended for the implementation of this research can run smoothly in accordance with expectations, here is the arrangement of learning implementation planning:

\section{1) Cycle 1}

\section{a) Planning}

The Planning was prepared based on the results of analysis and initial reflection on the problems and alternative solutions that might be done as a grade 6 teacher as well as researchers.

\section{b) Implementation}

The implementation of cycle 1 improvement was carried out by the researcher as a grade 6 teacher of SDN Sambungrejo Sukodono Sidoarjo, assisted by supervisoror as observer. Improved learning is carried out in accordance with the planned learning improvement steps; place and time 
has been agreed, i.e. in the class VI SDN Sambungrejo Sukodono Sidoarjo in one time face to face ( 70 minutes). In the implementation of cycle 1 improvement, it was used the planned and prepared learning model and the types and evaluation tools which developed together. The implementation procedures are as follows:

- Master greeting, checking student attendance

- The teacher identifies the characteristics of waking up the space

- Students are formed in several learning groups which are further caught up with the original group

- Students with serial number one in each group gathered in the corner of the class to discuss the build up of the cube which is then called the expert group

- After a few minutes the group of experts returns to the original group

- Each group is given LKS for discussion

- Each group presented the results of the discussion

- Each student is given an evaluation sheet

- The group that gets the best score will be rewarded

Cycle 2 was implemented as a result of reflection and evaluation in cycle 1 .

\section{c) Data Collection}

Data collection on process and result of learning improvement cycle 1 was done by writer as teacher, assisted by supervisor using data collection instrument which have been prepared through LKS assessment sheet. Data collection was done during the implementation of learning improvements. The data collected through the final test sheet were the values which provide information about the completeness of individual student learning outcomes at the end of the lesson.

\section{d) Reflection}

Reflection by the author at each meeting/cycle, and focused on the improvement aspects which carried out in cycle 1 .

The results of the reflection was used as materials to perform improvement planning in cycle 2, to further improve the success of expected improvement of learning.

\section{c) Analysis}

The data obtained were discussed with the supervisor. The results of these analyzes served as a benchmark in making cycle 2 improvement plan. From these analyzes, it was found shortcomings during the learning process. So that the implementation of learning in cycle 2 could run more optimal and obtain better results.

Reflections by the researchers at each meeting / cycle, and focused on the improvement aspects that have been done in cycle 2. Reflection was based on the data or findings recorded in the data collection instrument used, so that information about the weaknesses, shortcomings, and strengths of the learning improvements is made. Results of reflection is then by the authors used as material to create a report PKP.

\section{B. Data Analysis Technique}

The collected data were analyzed descriptively, both quantitative and descriptive qualitative descriptive [10]. The data analyzed descriptively quantitative is data about the volume of wake up space expressed with the score (score) achieved students from the test results.

The average results of student tests can be searched by the formula:

$$
\bar{X}=\frac{\sum X}{\sum N}
$$

Dengan :

$\bar{X}$ : average score

$\sum X:$ total value of all students

$\sum N$ : number of students

And to calculate the percentage of learning mastery used the formula as follows:

$$
p=\frac{\sum \text { students achieved average score }}{\sum N} \times 100 \%
$$

Qualitative data in the form of observation records, student portfolio documents and interview recordings were analyzed with qualitative analysis through stages: data exposure, data simplification and data grouping in accordance with the focus of problems and meaning.

\section{RESULTS AND DISCUSSION}

From the research it was obtained observation data in the form of observation of learning management using JIGSAW cooperative learning model and student formative test data on each cycle. Formative test data was used to determine the improvement of student achievement after applied learning with JIGSAW type cooperative learning model on the material volume of wake up space. The implementation of learning in each cycle can be explained as follows:

\section{A. Initial / Pre-cyclical Reflection Activity}

- This study was conducted after viewing the results of formative tests before the improvement of the volume of space wake. Where the results of formative tests with Minimum Exhaustiveness Criteria (KKM) 70 before the improvement obtained the following conclusions:

- 7 out of 28 students achieved complete mastery of the class or by $25 \%$

- The class average was 56.4

- Performed improvement of learning (cycle I) to improve student learning achievement.

\section{B. Results of Research in Cycle I}

\section{1) Action planning}

- Preparation done first by the researchers is to create a new learning plan (RPP) which includes JIGSAW cooperative learning model type. The purpose of learning is to improve students' ability in calculating the volume of wake-up space.

- Preparing the media in the form of wake-up space. 
- Preparing worksheets for students

- Prepare evaluation sheets

2) Activity and Implementation Stage Teacher explains the purpose of learning

a) Teachers do question and answer about waking up space

b) The teacher identifies the characteristics of wake up space including ribs, sides and vertices

c) Teachers form several study groups and apply JIGSAW type cooperative model

d) Group of experts includes groups of cubes, beams, prisms, conical pistons and tubes

e) Teacher distributes LKS to each group

f) Each group read out the results of the discussion

g) Discussion of the results of the discussion and explanation of the search for the geometric volume.

\section{3) Action Observations}

Observation activities are conducted in conjunction with the implementation of the action. Observations are made on the implementation of the actions and plans that have been made and their impact on the process and the instructional results by using the instrument of observation instrument in the form of evaluation sheet at the end of each lesson.

\section{4) Reflection}

This stage is the last stage of a learning process. This activity is a feedback on the implementation of learning. In fact, this feedback problem is usually neglected, but in fact it is very important for the success of a learning process. Without this stage, especially without feedback, the learning process has not run fully. Reflection is done at the end of each learning cycle. Researchers conduct data analysis to find out the constraints and changes that occur during the learning action implemented. At this stage of the reflection is determined whether the next cycle needs to be done. If necessary, then plan the next cycle. Based on the data in the first cycle obtained the following conclusions: a) Of the 28 students who achieve complete mastery of 12 students or completeness of the class by $43 \%$ b) The average class is 67 c) Second cycle is needed to complete student learning.

\section{Results of Research in Cycle 2}

1) Action planning

a) Preparation done first by the researchers is to create a new learning plan by including learning using JIGSAW type cooperative model and learning objectives is to increase students' ability in calculating the volume of space wake

b) Preparing the media in the form of spatial forms

c) Prepare the worksheet

d) Prepare evaluation sheets

\section{2) Action Observations}

Observation activities are conducted in conjunction with the implementation of the action. Observations are made on the implementation of actions and plans that have been made and their impact on the implementation of actions and plans that have been made and their impact on the process and the instructional results by using the instrument of observation instrument in the form of observation sheet and evaluation sheet at the end of each learning.

\section{3) Reflection}

This stage is the last stage of a learning process. This activity is a feedback on the implementation of learning. In fact this feedback problem is usually neglected, but in fact it is very important for the success of a learning process. Without this stage, especially without feedback, the learning process has not run fully.

Reflection is done at the end of each learning cycle. At this stage of the reflection is determined whether the next cycle needs to be done. If necessary, then plan the next cycle. Cycle II is implemented as cycle I.

Existing data are analyzed. Based on the data in the first cycle obtained the following conclusions:

a) Of the 28 students who achieve mastery learning as much as 23 students or completeness of the class of $82 \%$

b) The average class is 79.3

c) No cycle III is required because the class is complete learning

\section{Observation Results in Cycle 1}

a. Excess Cycle Action 1 1) Researchers carry out action research in accordance with the lesson plan that is using JIGSAW type coopeative learning model 2) Students are more active in learning so that the class becomes alive 3 ) Students are involved directly from the beginning of the lesson to the conclusion.

b. Lack of Cycle Action 1 1) There are still many students who are confused while in the group of experts 2) There is still a commotion when moving from group of origin to expert group and vice versa 4) Can be explained that the application of JIGSAW type cooperative learning model obtained the average score of student achievement is 79.3. The corrective action learning using JIGSAW type cooperative learning model on the material to find the volume of wake-up space otherwise successful if the average test results increase at least $10 \%$. The completeness of the class reaches $82 \%$ so that students have finished studying. this also has been in accordance with the wishes of researchers that the action of learning is declared successful when $75 \%$ have mastered minimal limitations or achieve KKM.

\section{E. Observation Results in Cycle 2}

1) Advantage of cycle 2

- Researchers carry out action research in accordance with the lesson plan that is using JIGSAW type cooperative method

- Students are directly involved with learning

- Students are very excited to follow the activities

2) Disadvantage of cycle 2

- Still seen the clever student dominance 
o There are still students who are confused when having to move from group of origin to expert group and vice versa

\section{CONCLUSION}

The use of JIGSAW model in the teaching and learning process in the field of mathematics study of materials calculate the volume of wake-up space proved to improve student learning achievement. This can be perceived from the increase in the average grade of the pre-cycle value of 56.4 to 67 on the cycle 1 and increased to 79.3 in cycle 2 . Student learning completeness in class also increased from $25 \%$ in pre-cycle to $43 \%$ in cycle 1 and $82 \%$ in cycle 2

The use of JIGSAW can increase student learning activity and activeness in classroom learning.

\section{Suggestions of Follow Up:}

a) The use of JIGSAW model should be applied more often as it has been indicated to improve learning activities and student learning outcomes.

b) Teachers should be wise to students who are less active in group discussions and give reward students who have the confidence to perform in front of the class to obtain accurate and more in-depth results, the results of this study should be acted upon and developed.

\section{REFERENCES}

[1] N. M. Webb, J. D. Troper, and R. Fall, "Constructive activity and learning in collaborative small groups.," J. Educ. Psychol., vol. 87, no. 3, p. 406, 1995.

[2] R. T. Johnson and D. W. Johnson, "Cooperative learning, values, and culturally plural classrooms," in Classroom Issues, Routledge, 2005, pp. 29-47.

[3] M. Ibrahim, F. Rachmadiarti, and M. Nur, "Ismono. 2000 Pembelajaran Kooperatif," Surabaya Pus. Sains dan Mat. Sekol. Univ. Negeri Surabaya.

[4] R. E. Slavin, "Instruction based on cooperative learning," Handb. Res. Learn. Instr., vol. 4, 2011.

[5] A. Robinson, Cooperative learning and the academically talented student. national research center on the gifted and talented, 1991.

[6] E. Aronson and S. Patnoe, Cooperation in the classroom: The jigsaw method. Printer \& Martin Limited, 2011.

[7] J. Garfield, "Teaching statistics using small-group cooperative learning," J. Stat. Educ., vol. 1, no. 1, 1993.

[8] R. M. Gagné and M. D. Merrill, "Integrative goals for instructional design," Educ. Technol. Res. Dev., vol. 38, no. 1, pp. 23-30, 1990.

[9] B. S. Bloom, M. D. Engelhart, E. J. Furst, W. H. Hill, and D. R. Krathwohl, Taxonomy of educational objectives: Handbook 1: Cognitive domain. Longman Publishing Group, 1984.

[10] E. T. Stringer, Action research in education. Pearson Prentice Hall Upper Saddle River, NJ, 2008. 